\title{
Training security managers in leadership competence as components of the national security system shown by the example of the War Studies University in Warsaw and of the Defence University in Brno
}

\author{
Edyta Ślachcińska1, ${ }^{*}$, Ilona Ziemkiewicz-Gawlik ${ }^{2}$, Maciej Marczyk ${ }^{3}$, Radomir Saliger ${ }^{4}$ \\ 1,2Wyższa Szkoła Bankowa w Poznaniu, ul. Powstańców Wielkopolskich 5, 61-895 Poznań, Poland \\ ${ }^{3}$ Akademia Sztuki Wojennej, al. gen. A. Chruściela „Montera” 103, 00-910 Warszawa-Rembertów, Poland \\ ${ }^{4}$ Univerzita Obrany, Kounicova 65, 662-10 Brno, Czechy \\ *email:edyta.slachcinska@wsb.poznan.pl
}

This is an open access article distributed under the Creative Commons Attribution License, which permits unrestricted use, distribution, and reproduction in any medium, provided the original work is properly cited.

\section{ARTICLE DETAILS}

\section{Article History:}

Received 02 october 2017

Accepted 06 october 2017

Available online 11 october 2017

Keywords:

national security, security

manager, leadership competence.

\section{ABSTRACT}

The article refers to research conducted at War Studies University in Warsaw and at Defences University in Brno amongst bachelor's degree students of the sixth semester of full-time studies studying in the fields related to security. The research aim was to identify leadership competence of the students.

\section{Introduction}

Safety issues are multidimensional. Territories may be considered now internationally, European, national and regional. National security in its modern sense is a social expectation to provide the possibility of using economic prosperity, social autonomy, and therefore it is the concept of existential needs and interests of human communities organized in the country [1].

The stability of state security depends on the interests of individual countries entering the international system and on external influences [2]. Efforts by the state, seeking on the one hand, to avoid any threats to their national security, and on the other to create agreements, norms, mechanisms and international organizations that allow you to solve the contradictions and conflicts and develop peaceful international cooperation [3].

The security system, in order to fulfill its role effectively and efficiently, must not only have the power to make the right decisions, but also be the force that will enable those decisions to be made. It involves the wellprepared and organized staff - security specialists, including security managers, who must be properly prepared to perform these functions, especially to educate them in leadership competencies. The education of safety managers can thus become the most important task of teaching for all types of universities in the fields of security studies.

\section{National security}

Security is a very broad term and is defined differently by scientists. However, everyone underlines their importance in the functioning of the state and ensuring adequate protection of citizens.

According to R. Zięba, in the sense of social security, it covers the needs of existence, survival, certainty, stability, identity, independence, protection of the level and quality of life. Security, being the primary need of man and of social groups, is at the same time a fundamental need of states and international systems: its lack causes anxiety and a sense of threat [4]. The above definition considers security as the highest value in the lives of every person and nation. This is the existential necessity of all individuals, groups and states. The national security dictionary defines safety as a condition that gives confidence and guarantees of behavior and a chance to improve. It is a situation characterized by the risk of losing something that a person particularly values, for example: health, work, respect, feelings, material goods [5]

The assurance of such security is practically impossible to achieve because there can always be a destabilizing factor, such as a flood, ecological catastrophe, a terrorist attack that can not be foreseen.

In this context, the task of today's state is to minimize uncertainty and to prepare state structures for the removal of the effects of potential threats. This results in the national interests in the security field to which belong:

- Capability to have an effective national security that ensures preparedness and ability to prevent threats, including deterrence, defense and protection, and to eliminate their consequences.

- The strong international position and the membership of credible international security systems.

- Individual and collective protection of citizens against threats to their lives and health and against the violation, loss or degradation of material goods (material and non-material).

- Ensuring the freedom of citizens to exercise their rights and freedoms without harming the safety of others or the security of the state and ensuring national identity and cultural heritage.

- To ensure sustainable development of the social and economic potential of the state, with particular emphasis on the protection of the environment and living and health conditions of the population as a basis for living.

W. Kitler claims that: "National security is the most important value, the national need and the priority goal of the state, individuals and social groups, and at the same time a process that encompasses a variety of means to ensure lasting, interference free and national development, including defense and protection. The state as a political institution and 
the protection of individuals and the whole of society, their goods and the environment from threats which significantly limit its functioning or impair its goods subject to special protection [6]".

The importance of national security can be considered in three ways [7]:

- In the central social category meaning - security is for individuals, social groups and the state the primary existential need, and at the same time is the overriding goal of state and social organization.

- In functional meaning - security is the overriding national mission of society and the state, which consists in protecting and defending national values and interests against potential and real threats and creating conditions for free development..

- In structural meaning - ss the overall organization and preparation of the state to create national security based on civil and military organization of protection and national defense.

Looking at the armed conflicts (wars) that took place in Europe at the end of the twentieth century and now (the war in former Yugoslavia, the conflict in Georgia, crisis in Ukraine), one should assume that there is no certainty as to the full security.

The dangers of national security are inextricably linked to the international situation and threats generated in the regional and global environment. The collapse of the bipolar system has eliminated the threat of nuclear confrontation between the opposing sides, at the same time resumed silent conflicts and new threats to peace and international stability emerged. Economic crises, ethnic and religious conflicts, human rights violations, proliferation of weapons of mass destruction, political instability, terrorism and organized crime are new challenges facing the international community [8].

\section{System of the national security}

National security is one of the principal directions of the state's activities in both peace and war-time development. It constitutes the ability of the state to effectively counteract and eliminate threats to the citizen and the entire state. The security field is complex and is of interest to the whole public administration, public administration and national economy [9]. Presented above is a system of national security, which is treated as a whole forces, means and resources allocated by the state to carry out tasks in the field of security, according to these tasks organized, maintained and prepared, in which distinguished management subsystem and a number of sub-regulations [10].

The entities of this system are: President of the Republic of Poland, Parliament, Council of Ministers, central government administration, as well as armed forces, services and institutions responsible for: prevention and countermeasement of external threats, public safety, rescue operations, protection of the population and property in the presence of citizens. It is essential that the national security system is organized and equipped to guarantee rapid and effective action in situations of all kinds of crises and threats. Therefore it should have the following elements [11]:

- The politics and the strategy of the national security.

- Legal basis of the security.

- Infrastructure of the security.

- Protection organisation and civil and military defence activities

- Education of the security.

- The international cooperation and alliances from the margin of safety.

It is therefore appropriate to properly prepare educational programs (higher education programs) in higher education so as to give the highest possible level of preparation for future managerial positions (leaders, leaders, managers) for the national security area.

\section{Essence of the security manager work}

The manager is the person who manages the organization or the area of its activity [12]. The basic task of the manager is to realize the management process. According to F. E. Kast and J. Rosenzweig, management is the process of coordinating collective efforts to achieve organizational goals by people, using technology, in structured structures, based on assigned tasks [13].

H. Mintezberg, based on observations of a group of directors in their daily work, following step by step the actions described managerial roles and each role attributed the implementation of specific tasks. The manager's role according to $\mathrm{H}$. Mintezberg are as following [14]:

- Interpersonal roles (leadership roles of a representative, leader, and liaison that provide for relationships with other people).

- Information roles (manager roles as observer, information propagator and the spokeman that require information processing).

- Decision-making roles (manager roles as disruptive entrepreneurs, resource disposers and negotiators, and above all refer to decisions that need to be taken).

The role played by the manager depends on his position and the nature of the job. Managers, depending on where in the organizational hierarchy and the nature of work, can be divided into [15]:

- Top managers are a relatively small group of executives. These include, but are not limited to, persons in positions of president, vice president or general manager. They set the goals of the organization, its overall strategy, and its operational policy. They also take responsibility for the overall management of the organization and represent the organization in external contacts.

- Mid-level managers are the largest group among all the people in the management. People in positions of plant managers, department heads or team leaders. They are responsible for executing policies and plans developed by senior managers and overseeing and coordinating the activities of downstream managers. The task of middle managers is to control the actions that lead to the implementation of the current corporate policy.

- $\quad$ Managers of the lowest level, supervise and coordinate the work of the executive staff. They are determined as "surveillance workers". This group includes, for example, a foreman and a master or even an office manager. These posts are the first executive posts of employees promoted from the executive staff.

The above-mentioned management levels can be distinguished in each organization [16]. A particular type of organization is the state, and the management of the national security system is a special type of management. The people responsible for managing the national security system are security managers. Depending on management levels, the following security managers can be distinguished:

- The strategic level (highest level of management) is the Parliament the President, the Council of Ministers. They define the mission of the state, identify the state's security strategy, including strategic goals (what to do, when to follow? in what direction?), And some means and methods of achieving objectives.

- $\quad$ Tactical level (medium level of management), Ministers, heads of the main government administration, voivods. They focus on ways to achieve strategic goals (how to implement them, when, when, by what specific methods and means?).

- Operational level (lowest level of management), are self-government administration bodies as well as entrepreneurs performing tasks in the field of state security. They focus on the task execution system and on-going control over their execution (Whoever? When? Where? By what specific means and methods, will carry out specific goals?).

National security management is, in the simplest terms, the responsibility of the competent authorities (security managers at the various levels of management), within the confines of their competence, to maintain the desired level of security in all areas of the state's operations and to take adequate action if threats occur [17]. Security managers are at the forefront of the teams and are responsible for the actions of their subordinates. It can therefore be said that a security manager is a person whose primary task is to lead the work of human teams in the structures of public administration, organizations working for national and international security, scientific research institutes, educational and academic institutions dealing with security issues to ensure security of the countries.

To achieve this goal, the following actions need to be taken: threat 
monitoring, prevention, prevention and removal, and defense management [18].

The basic issues in the process of national security management are adequate management staff, so special attention should be paid to the training of safety managers.

\section{Training the leadership competences of the security managers at the War Studies University in Warsaw and at the University of the Defence in Brno on the Bachelor's degree studies}

R. E. Boyatzis defines competence as the potential that exists in a human being, leading to behavior that contributes to satisfying the requirements of a given workplace within the organization's surroundings, which in turn produces the desired results [19]. R. Stępień perceives the competence slightly differently, talking about them, lists the so-called key skills. They are: the ability to communicate, interact, solve problems, exert a desired influence, be a leader, plan for self-learning, use information processing and storage [20].

Competence within their specific domain of work is the set of characteristics of a person, which is characterized by elements such as motivation, personality traits, abilities, self-esteem associated with group functioning, and the knowledge that person has acquired and used [21]. Leadership competencies, on the other hand, are a coherent and functional experience system, personality conditions, abilities and skills that ensure effective and responsible influence of subordinates and group resources (organizations) to achieve common goals and satisfying important primary needs [22]. Leadership can be understood both as a process and as a property. In the case of treating leadership as a property, the accent is placed on the personal qualities attributed to the leaders. With this statement, E. Ogbonna and L. Harris claim that there is a certain configuration of characteristics which, independently of other conditions, guarantees the authority necessary to lead others [23]. On the basis of an analysis of literature were distinguished the leadership competence that security managers should have:

- composed (calm) in difficult situations,

- energetic in action, likes challenges,

- self-confident, bold in expressing his own opinions,

- consistent and persistent in pursuing of the goal,

- easy to gain confidence, of uniting others,

- feeling empathy (of understanding emotions and the situation of other person),

- urgent, punctual, likes order,

- makes decisions easily and quickly,

- takes responsibility for its action

- ability to motivate others,

- ability of the cooperation in the group,

- team management skills,

- is able to work under pressure of time,

- is able to convince other to one's ideas,

- a responsibility for its and others action,

- act in accordance with promises, is a man of his word.

Within the framework of the research, a diagnostic survey was conducted with the questionnaire technique among students of the 6 semesters of first-cycle full-time military studies, studying in the field of Internal Security at the War Studies University in Warsaw and in Security Management at the Defence University in Brno.

The main aim of education at both universities is to seek new solutions, within the framework of their classes, in the functioning and improvement of the national security system, to prepare students for functioning in the most important subjects of the system, to prepare them for the challenges of the future including functioning in conditions of accelerated socialeconomy development of the country, globalization and the unpredictability of modern threats.

The implementation of the didactic process is aimed at preparing graduates as specialists in the organization and functioning of the security system in public administration and business entities.The programme graduate qualified for middle management positions within the defence department, possibly in organizations involved in ensuring state security. The programme graduate qualified for middle management positions within the defence department, possibly in organizations involved in ensuring state security.

The purpose of the study was to identify the student's leadership competencies. The research tool was a questionnaire survey. The study was conducted among 140 full-time students (84 students in Warsaw and 56 in Brno). Students in Warsaw were involved in civilian studies, in the field of Internal Security, and were involved in the following areas: Public Safety, General Security and Social Security. However, the students in Brno are students of military studies, in the field of Security Management and specializations: Civil Protection, Security Services i Cybernetics Security. The programme syllabi simultaneously develop adequate studies oriented by military branches which form conditions for mastering the wide scale of significant knowledge necessary for a contemporary military professional and career officer in the Czech Army. Studies of such a focus respond to the request of career permeability within the dynamically developing military structures.

TABLE 1. Basic characterization of examined groups of students [\%].

\begin{tabular}{|c|c|c|c|}
\hline Criteria & Warsaw & Brno & Together \\
\hline \multicolumn{4}{|l|}{ Gender } \\
\hline Woman & 48 & 11 & 33 \\
\hline Man & 52 & 89 & 67 \\
\hline \multicolumn{4}{|l|}{ Age } \\
\hline To 25 years old & 100 & 93 & 97 \\
\hline 25-35 years old & 0 & 7 & 3 \\
\hline Above 35 years old & 0 & 0 & 0 \\
\hline \multicolumn{4}{|l|}{ Professional status } \\
\hline employed & 26 & 100 & 55 \\
\hline unemployed & 74 & 0 & 45 \\
\hline \multicolumn{4}{|l|}{ Work } \\
\hline assent with the course of studies & 18 & 100 & 76 \\
\hline dissent with the course of studies & 82 & 0 & 23 \\
\hline
\end{tabular}

Students from both sexes participated in the survey. At the War Studies University in Warsaw, the majority of them are male (52\%), women are $48 \%$. At the Defense University in Brno, the studies are dominated by men, $89 \%$ of men and only $11 \%$ of women.

At both colleges are studying young people, at the War Studies University all examined students are below the age of 25, at Defences University Students in this age group constitutes $93 \%$, and $7 \%$ are $26-35$ year old. Most students from Warsaw (74\%) are unemployed, which may be due to the fact that the surveyed respondents study in full-time studies and the distribution of activities in the plan on a particular day of the week is large. The reverse situation is at the University of Brno, namely $100 \%$ of students took up the job there. At the University of Defense in Brno, in the group of working people, all students have a job related to the field of study. This is related to the fact that once an applicant for military in-site studies receives the notification of acceptance and meets all conditions of military professional service, the appropriate order of military professional service call is delivered afterwards. As on the day of recruitment the applicants are enlisted to a Czech Army training base for a two-month basic military training that precedes university studies.

Passing the basic military training the applicants are transferred to the University of Defence at the positions of military university students, 
[3] W. Multan, Wizje bezpieczeństwa europejskiego, Warszawa (1997), p. 14.

[4] R. Zięba, Pojęcie i istota bezpieczeństwa państwa w stosunkach międzynarodowych „Sprawy Międzynarodowe”, 10 (1989), p. 50.

[5] Słownik terminów z zakresu bezpieczeństwa narodowego, AON, Warszawa (2008), p. 13.

[6] W. Kitler, Bezpieczeństwo narodowe RP. Podstawowe kategorie. Uwarunkowania. System. AON, Warszawa (2011), p. 31.

[7] R. Jakubczak, J. Flis, Bezpieczeństwo narodowe Polski w XXI wieku. Wyzwania i strategie, Wydawnictwo Bellona, Warszawa (2006).

[8] D. B. Bobrow, Złożoność problematyki braku bezpieczeństwa. Implikacje redefinicji pojęcia [w] D. B. Bobrow E. Haliżak, R. Zięba, Bezpieczeństwo narodowe i międzynarodowe u schyłku XX w., Scholar, Warszawa (1997).

[9] J. Wojnarowski, Gotowość systemu bezpieczeństwa narodowego, AON, Warszawa (2010), p. 19

[10] Strategia Rozwoju Systemu Bezpieczeństwa Narodowego Rzeczypospolitej Polskiej 2022, przyjęta uchwałą Rady Ministrów dnia 9 kwietnia 2013, Biuro Bezpieczeństwa Narodowego, Warszawa (2013).

[11] J. Marczak, Bezpieczeństwo Polski. Pojęcie i zakres bezpieczeństwa narodowego, [w] J. W. Kaczmarczyk, R. Socha, J. Grzyb (red.), Wybrane zagadnienia edukacji dla bezpieczeństwa, Mazurski Ośrodek Doskonalenia Nauczycieli, Ełk (2010).

[12] F. Gao, M. Li, S. Clarke, Knowledge, management, and knowledge management in business operations. Journal of Knowledge Management, 12(2), (2008), pp. 3-17, doi:10.1108/13673270810859479
[13] B. Kaczmarek, C. Sikorski, Podstawy zarządzania, Łódź (1999), p. 37.

[14] H. Mintezberg, Managerial work: Analysis from Observation, October (1971), p. 97.

[15] R.W. Griffin, Management, Cengage Learning (2016).

[16] M. Jasiulewicz-Kaczmarek, K. Szwedzka, Were our leaders ready to implement the changes? - a case study, in: Yue X.-G., Duarte N.J.R. (eds.), Proceedings of the 2016 International Conference on Economics and Management Innovations, part of Advances in Computer Science Research vol. 57, pp. 267-271(2016), doi: 10.2991/icemi-16.2016.6

[17] W. Molek, K. Stec, R. Marciniak, Zarządzanie kryzysowe w systemie kierowania bezpieczeństwem narodowym [w] Bezpieczeństwo Narodowe, I - 2011 / 17, p. 47.

[18] Rozporządzenie Rady Ministrów z dnia 27 kwietnia 2004 r. w sprawie przygotowania systemu kierowania bezpieczeństwem narodowym (Dz. U. z 2004 r. Nr 98, poz. 978).

[19] R. E. Boyatzis, The Competent Manager. A model for effective performance, New York (1982), p.18.

[20] A. Kucharbíková, E. Tokarbíková, M. Blašková, Human Capital Management - Aspect of The Human Capital Efficiency in University Education, Procedia - Social and Behavioral Sciences 177, pp. 48 - 60 , (2015)

[21] S. Whiddett, S. Hollyforde, A Practical Guide to Competencies: How to Enhance Individual and Organisational Performance, CIPD Publishing, London 2003, p. 13

[22] J. Borkowski, M. Dyrda, L. Kanarski, B. Rokicki, Człowiek w organizacji. Podręczny słownik psychologii zarządzania i dziedzin pokrewnych, Warszawa (2001), pp. 59-60.

[23] E. Ogbonna, L. C. Harris, Leadership style, organizational culture and performance: empirical evidence from UK companies, The International Journal of Human Resource Management (2000), p. 767. 